\title{
Corpus-Based Versus Traditional Collocation Learning: The Case of Iranian EFL Learners
}

\author{
Elham Mohammadi Foomani (Corresponding author) \\ Dept. of Languages \& Literatures, University of Tehran \\ Northern Amirabad, Tehran, Iran \\ E-mail: foomanielham@ut.ac.ir \\ Karim Khalaji \\ Languages \& Linguistics Center, Sharif University of Technology \\ Tehran, Iran \\ E-mail: karim_khalaji@yahoo.com
}

Received: January 23, 2016 Accepted: March 6, 2016 Published: March 9, 2016

doi: $10.5296 /$ jsss.v3i2.8922

URL: http://dx.doi.org/10.5296/jsss.v3i2.8922

\begin{abstract}
A vital aspect of word knowledge is knowledge of collocations. Regarding its central role in accurate and fluent use of words, it is essential to consider collocation learning as integral to the study of vocabulary. While different methods are proposed for teaching collocations, the efficiency of these methods is yet subject to question. This study sought to investigate the effectiveness of corpus-based learning of verb-noun collocations as opposed to the traditional methods. To this aim Collin Collocation Dictionary was used as a concordancing tool for learning collocations. Forty five upper-intermediate students divided randomly into control and experimental groups were studied. A pre-test was conducted to both groups before the experiment. Next, in 4 subsequent weeks, the experimental group was provided with 24 concordance collocations and was required to identify the collocations and miscollocations while the control group received traditional collocation training through texts. At the end of the teaching procedure a post-test as well as a writing task were administered to compare students' collocation learning and their accurate application of collocations in the writing task. In a final step, an interview was conducted to gain insight into students' perceptions of the design. The results indicated the experimental groups' advantage in collocation acquisition as
\end{abstract}


well as their application in writings. The interview results with seven students indicated their positive perceptions of the corpus-based design despite the reported limitations.

Keywords: Collocation, Corpus-based, Concordance, CALL

\section{Introduction}

Vocabulary learning constitutes an integral part of second language learning (Schmitt, 2008). As Wilkins (1972, p.111) argues "little can be conveyed without grammar but nothing can be conveyed without vocabulary". Vocabulary knowledge is comprised of various aspects among which the most problematic area for EFL learners is collocation. Fluent production of language is strongly influenced by the use of pre-fabricated chunks of language by students; efficient knowledge of collocations plays an outstanding role in enhancing speaking fluency (Lewis, 2000; Sung, 2003). Furthermore, it can improve their comprehension of natural language (Nesselhauf, 2005).

Different definitions have been proposed for collocation in the literature. According to Lewis (2000), it is "the way in which words co-occur in natural text in statistically significant ways" (p. 132). A more recent definition of collocation by Webb, Newton and Chang (2013) regards collocation as "the regular co-occurence of words within a given span demonstrating a statistical strength of co-occurence." (p. 92).

Liu, C., P. (1999) analyzed collocation errors of Chinese students of English in their final papers as well as compositions and reported that the most frequent collocation errors appeared to be verb-noun collocations. Later Liu, L., E (2002) examined the verb-noun miscollocations and showed that $87 \%$ of the miscollocations were of the verb-noun collocation type. On a similar study, Nesselhauf (2003) investigated collocations in the writing of German advanced EFL learners. The results of his study revealed that the most frequently miscollocated vocabulary was related to wrong choices of verbs. Despite the significant role of verb-noun collocations and the students' erroneous attempts to use them, few studies have dealt with teaching verb-noun collocations, their impact on productive language (Hsu \& Chiu, 2008; Sung, 2003) and the processes involved in collocation acquisition through recent technological approaches. The findings of the few studies available indicate that corpus-based activities for collocation learning can be beneficial (Chao, 2010; Wu, Franken, \& Witten, 2012). This study, therefore, aims to compare the effectiveness of two collocation teaching methods, i.e. traditional and corpus-based in students' collocation acquisition and their subsequent use in writing.

\section{Review of the Related Literature}

It is widely supported in the literature that not only can collocations be particularly important in language competence of students at all levels, but they are also influential in enhancing students' accuracy and fluency (Nation, 2000; Nesselhauf, 2003; Wray, 2002). Since collocations are subsumed under formulaic expressions, they are vastly present in the native language and constitute almost half of native speakers' spoken and written discourse (Howarth, 1998; Shehata, 2008). Similarly for EFL learners, the use of collocations has been associated with generally productive language (Bazzaz, Samad, Ismail, \& Noordin, 2015; Hsu \& Chiu, 2008) and particularly writing performance of students (Bazzaz \& Samad, 2011; Mounya, 2010; Yeh, Liou, \& Li, 2007). Many students lose scores for their lack of 
collocation knowledge and this is a daunting challenge for EFL learners (Wu et al., 2010). As stated by Nesselhauf (2003), despite the emphasized role of collocations in language competence, collocation teaching and students' collocational problems have not yet been investigated in detail.

Literature abounds with reports of students' second language (L2) collocational problems (Koosha \& Jafarpour, 2006; Shokouhi \& Mirsalari, 2010). Youmei and Yun (2005) reported that even advanced EFL learners have difficulties in producing collocations. The majority of students' collocational concepts are based on their first language (Howarth, 1998; Schmitt, 2004; Wray, 2002). The problem lies in the fact that learners start learning an L2 as single words in contrast to native speakers (Schmitt \& Underwood, 2004).

\subsection{Types of Collocation}

Collocations are categorized into two major types: Lexical and grammatical (Benson, Benson, \& Ilson, 1997). Lexical collocations, unlike grammatical collocations, do not consist of prepositions, infinitives or relative clauses; rather they consist of various combinations of nouns, verbs, adjectives or adverbs. Similarly Lewis (2000) defines lexical collocations as "combinations of two equal lexical components" (p. 133). Lexical collocations have attracted much attention in collocation literature (see, for example, Bagherzadeh Hosseini \& Akbarian, 2007; Hsu \& Chui, 2008; Lin, 2002). Since lexical collocations are both more frequent (Bensen et al., 1997) and more problematic for students, verb-noun collocations as a sub-category of lexical collocations are the subject of this study.

\subsection{Teaching Collocations}

In recent years and after a period of ignorance (Kennedy, 2008) collocations are again central to second language acquisition (SLA) practices again (Agah \& Soori, 2015; Chan \& Liou, 2005; Duan \& Qian, 2012; Goudarzi \& Moini, 2012; Lewis, 2000; Nation, 2001). Two main views have been suggested for collocation teaching: corpus-based view and traditional methods.

\subsubsection{Traditional Methods}

With recognition of the significance of collocations in language competence, teachers have developed diverse classroom activities for collocation learning and long-term retaining. Lewis (2000) in his book proposed plenty of collocation activities. Also some studies have been conducted on explicit instruction of collocations in traditional classroom settings and have indicated positive impacts of collocation instruction on writing (Liu, 2002), receptive and productive collocations (Lin, 2002) as well as collocation production (Tseng, 2002). However, the problem is that the approaches taken so far for teaching collocations have often been grammar-based and concerned with the end product. This is while just presenting language in isolation is not sufficient for language proficiency and providing L2 learners with the context in which a word is used is more helpful (Anthony, 2006) and solves students writing problems (Yoon, 2008).

\subsubsection{Corpus-based Methods}

Among the wealth of approaches proposed for collocation teaching, Sinclair (2003) believes the corpus-based method is the most recent and informative method, through which a vast 
amount of data can be analyzed quickly. Despite the advances in technology-assisted learning and the new dynamics proposed for language learning, few studies have investigated computer assisted collocation learning. Most research focus on vocabulary learning in isolated forms disregarding the context and co-text. A concordancer is a complex computer program consisting of large amounts of information in the form of computer language corpora which is "accessible to encourage data-based inductive learning" (Chan \& Liou, 2005 , p. 233). Concordancers provide opportunities for analyzing collocations. Computer concordancers are efficient learning tools which provide students with collocations in naturally occurring contexts (Wu et al., 2010).

Few researchers have studied the use of concordances to teach collocations in authentic contexts (e.g. Chang \& Sun, 2009; Wang, 2002). While Serpil and Yukselir (2015) proved the impact of corpus-based activities on verb-noun collocation learning in EFL classes, Abu Alsharr and Abu Seileek (2013), found that students who had experienced corpus-based instruction of collocations were not only better at using word collocations but they also outperformed in their writing. In line with their study, Yeh, Liou, and Li (2007) concluded that students used more appropriate vocabularies in their writing after experiencing concordancers in the process of collocation learning. Anthony (2006) reported that since using a concordance shows the use of language in various contexts, it leads to better application of collocations and thus improves students writing productions. Yoon (2008) investigated the influence of concordancing on six L2 learners' writings over an extended period of time; he suggested the positive effects of this approach and suggested that it helped the students solve their writing problems.

Some other studies have dealt with students' attitudes towards the use of this approach and reported their positive perceptions (e.g. Chang \& Sun, 2009; Vannestal \& Lindquist, 2007; Yoon \& Hirvela, 2004). Regarding learners' behavior in the approach Yoon \& Hirvela, 2004 mentioned an enhancement in L2 writing confidence among students, while Yoon (2008) reported the role of this approach in their feeling more responsible and becoming independent writers. On the down side, however, Vannestal and Lindquist (2007) reported that the method seemed difficult or boring to some especially weak students.

In an Iranian context Pirmoradian and Tabatabaei (2012) explored the influence of using Collins Collocation Dictionary as a concordancing tool on learning lexical collocations of Iranian EFL university students and concluded that the experimental group significantly performed better on lexical collocations. In a similar study, Koosha and Jafarpour, (2006) compared the traditional vs. data driven teaching of proposition and its collocations and found that the experimental group outperformed in learning propositions and their collocations. Jafarpour, Hashemian and Alipour (2013) compared the effects of corpus-based and conventional method of collocation teaching and reported the positive effects of corpus-based approach regarding comprehension and production of collocations.

\section{The Present Study}

In the light of previous research and regarding the fact that the role of corpus-based concordancing as a natural language processing tool can be a valuable resource for students (Anthony, 2006), and due to the close relationship between collocations and writing 
production, this study aims to investigate Iranian EFL learners' traditional and corpus-based verb-noun collocation learning and attempts to study the use of acquired collocations by students of the two groups in a subsequent writing. To this aim, the following research questions are posed:

1) Is there any significant difference between corpus-based and traditional methods with regard to Iranian EFL learners' verb-noun collocation learning?

2) Is there any difference between the two methods regarding students' use of collocations in their writing?

3) What are students' perceptions of the online corpus-based collocation learning method?

\section{Method}

\subsection{Participants}

A total of 45 male and female EFL students from three general English classes in Zabansara language institute in Zanjan, Iran participated in this study. The students were MSc and BSc students and non-English majors. Since they were all Iranians they shared their first language (Persian) and societal backgrounds. Their age ranged from 20 to 30 and based on the institute's placement test, they were at three levels of second language proficiency. The participants were selected based on cluster sampling to make sure that students from three levels of proficiency were present in the study. The rationale for choosing students from different L2 proficiency levels was to make sure that their proficiency did not influence their performance in collocation learning. In order to investigate the impact of corpus-based versus traditional methods of collocation teaching on students' learning, the participants were divided into two experimental and control groups. Group 1 (experimental) comprised 22 students who were taught through corpus-based method in a computer lab and Group 2 (control) consisted of 23 learners who were taught in the class-room context and through traditional collocation-learning methods. Finally the students who did not manage to complete all the steps of the study were excluded and this left the study with 40 students.

\subsection{Instruments}

\subsubsection{Collocation Test}

In order to test students' knowledge of verb-noun collocations, a pre-test was designed for all the students by the researchers. The test comprised two sections. Section 1 consisted of 8 True/False items where students identified whether the collocations provided in each item was correct or false and if they knew the right collocation for the verb in that context. Section two of the test comprised 12 multiple choice items and the students were required to fill in the blanks in each item with the correct collocation. To test students' collocation learning after the four tutorial weeks a post-test was designed with the same format. Care was taken to include only verb-noun collocations in both tests, since it is the most problematic area for students (Liu, 2002; Nesselhauf, 2003).

\subsubsection{Writing Task}

After the instruction, the students were asked to write an essay about the topics previously covered in the course book during the semester. The related collocations had already been 
reviewed.

\subsubsection{Interview}

A semi-structured interview was designed by the researchers which included five questions aimed at gaining some information about the students' perceptions towards the teaching of collocations in the experimental group. The questions asked if students liked the way collocations were taught, or if they perceived any positive or negative effects in this method etc. As the questions in the interview were open ended, students could feel free to talk about related issues to the questions.

\subsection{Teaching Procedures in the Two Groups}

As explained earlier, the two groups were exposed to two different types of instruction. While the content of instruction was the same in the two groups, it was different in the form, i.e. the way those materials were taught to students. The course book for students in general English classes in the institute was American English File (Oxenden \& Latham-Koenig, 1997). In 4 subsequent weeks, both groups were taught 24 collocations. Concordance practice was implemented in the experimental class, in each session the experimental group was provided with 6 concordance collocations and was required to identify the collocations and miscollocations. Collins Collocation Dictionary was used as the concodancer for the experimental group while the students in the control group were taught collocations using traditional teaching method without the use of any concordancers. It is worth mentioning that the collocations were selected from the course book they were studying. Even though all of the participants had previously agreed to be included in the research study, no information was given to them regarding the exact time of the study.

In addition to teaching collocations, alongside with covering the course book, teachers in the two classes specifically practiced essay writing with the students and taught them the basic principles of writing an academic piece of writing. In the assignments they were asked to write essays about the topics that the teacher specified for them and their papers were corrected considering the general rules of essay writing such as main ideas, supporting ideas, examples and the order they appeared in the essay as well as cohesion and coherence. But the miscollocations were not rectified in their writing. The justification for this ignorance was that this way the students mostly paid attention to the structure of their writings, enabling researchers to gain insight to the natural use of collocations in their writing which represents the effect of teaching collocations in their writing skills and the practical application of collocations in their language products.

\subsection{Data Collection Procedure}

The students first took a pretest related to verb-noun collocations which served two purposes: to form a basis that enabled researchers to assess students' knowledge of collocations before the study which could subsequently be used to estimate the efficacy of each teaching approach later, and to make sure that the students in the two groups were not statistically different before the study, so that any possible improvements could be attributed to the teaching procedures they experienced, not to the preexisting differences they had at the beginning of the study. After taking the pretest the students were instructed for 4 weeks and at the end of the teaching procedure were asked to take the second collocation test as well as a 


\section{Macrothink Institute ${ }^{\mathrm{TM}}$}

writing task aimed to clarify the short term effects of the two teaching procedures on their knowledge of collocation and their application in writing. To gather information about students' perceptions, 7 students from the experimental group voluntarily participated in the semi structured interview developed beforehand.

\section{Results and Discussion}

The first research question addressed the effect of using the concordancer on students' verb-noun collocation knowledge to see which teaching process was more advantageous: the traditional way of teaching collocations or a corpus-based teaching of collocations. A one-way between-groups analysis of covariance (ANCOVA) was conducted to compare the effectiveness of the two different collocation teaching procedures designed to improve students' knowledge of collocations. The independent variable was the collocation teaching approach that each group was exposed to. The dependent variable was their performance in collocation test after they were taught collocations, and students' performance at the pretest which represented their knowledge of collocation before the study was considered as the covariate in this analysis. Preliminary checks were conducted to ensure that there was no violation of the assumptions of normality, linearity, homogeneity of variances, homogeneity of regression slopes, and reliable measurement of the covariate.

Table 1. Descriptive statistics

Dependent Variable: PostTtest1

\begin{tabular}{llll}
\hline Group & Mean & Std. Deviation & $\mathrm{N}$ \\
Experimental & 14.10 & 3.386 & 20 \\
Control & 10.78 & 2.777 & 18 \\
Total & 12.53 & 3.501 & 38 \\
\hline
\end{tabular}

Table 2. Levene's test of equality of error variancesa

Dependent Variable: PostTtest1

\begin{tabular}{lccc}
\hline $\mathrm{F}$ & $\mathrm{df1}$ & $\mathrm{df2}$ & Sig. \\
.118 & 1 & 36 & .733 \\
\hline
\end{tabular}


Table 3. Tests of between-subjects effects

Dependent Variable: PostTtest1

\begin{tabular}{lllllll}
\hline Source & $\begin{array}{l}\text { Type III Sum of Df } \\
\text { Squares }\end{array}$ & $\begin{array}{l}\text { Mean } \\
\text { Square }\end{array}$ & F & Sig. & $\begin{array}{l}\text { Partial Eta } \\
\text { Squared }\end{array}$ \\
$\begin{array}{l}\text { Corrected } \\
\text { Model }\end{array}$ & $336.001^{\mathrm{a}}$ & 2 & 168.000 & 50.054 & .000 & .741 \\
Intercept & 332.501 & 1 & 332.501 & 99.066 & .000 & .739 \\
PreTest & 231.438 & 1 & 231.438 & 68.955 & .000 & .663 \\
Group & 94.438 & 1 & 94.438 & 28.137 & .000 & .446 \\
Error & 117.473 & 35 & 3.356 & & & \\
Total & 6416.000 & 38 & & & & \\
Corrected & 453.474 & 37 & & & & \\
Total
\end{tabular}

Table 4. Estimates

Dependent Variable: PostTtest1

\begin{tabular}{lllll} 
Group & Mean & $\begin{array}{l}\text { Std. } \\
\text { Error }\end{array}$ & \multicolumn{2}{l}{$95 \%$ Confidence Interval } \\
& & & Lower Bound & Upper Bound \\
\hline Experimental & $14.023^{\mathrm{a}}$ & .410 & 13.191 & 14.855 \\
Control & $10.864^{\mathrm{a}}$ & .432 & 9.987 & 11.741 \\
\hline
\end{tabular}

As Tables 3 and 4. suggest, after adjusting the pretest scores, it was found that students in the experimental group $(\mathrm{M}=14.02, \mathrm{SD}=.41)$ significantly outperformed $[\mathrm{F}(1,35)=28.13, \mathrm{p}=.00$, partial eta squared $=.44]$ the students in the control group $(\mathrm{M}=10.68, \mathrm{SD}=.43)$ in the posttest that measured their knowledge of collocation after being taught. This means that teaching verb-noun collocations using concordancers is far more effective than teaching with the traditional ways of collocation instruction. This conclusion seems rational on the ground that using concordancers, students have more opportunities to be involved with language 
materials and the different contexts in which they might happen. As Wu et al. (2010) assert, computer concordancers are efficient learning tools which provide students with collocations in naturally occurring contexts. Concordancers also provide opportunities for analyzing collocations. This finding of the present study supports Pirmoradian \& Tabatabaei's (2012) study which using Collins Collocation Dictionary as a concordancing tool proved its positive role in lexical collocation learning of Iranian EFL learners. It is also partly in line with the findings of Koosha and Jafarpour, (2006) which proved the data driven teaching of proposition and its collocation in KWIC (keyword in context) positively affected students' learning propositions and their collocations. It is also in line with previous research on the efficacy of concordancing in collocation learning (Wang, 2002; Chang \& Sun, 2009). With regard to the impact of corpus-based activities on verb-noun collocations, this finding affirms Serpil and Yukselir's (2015) study results.

To answer the second research question i.e. how the use of concordancers could affect the use of collocations in writing, the students' writings were evaluated based on the appropriate use of collocations. Students' essays in the final exam were scored by two MA holders of TEFL who had a good command of English. The means for the two scores was considered as the score to be included in the data analysis. To eliminate any possible bias, all the papers were mixed and then scored. It should be noted however, that there was a relatively high inter-rater reliability between the two raters in the way they scored the written essays in terms of the appropriate use of collocations. This is evident in the pilot scoring test the researchers held before the study. The two raters were asked to score written essays of 15 students who were studying English in the same language institute in Zanjan and were similar to the participants of the main study.

Table 5. Correlations between two sets of scorers

\begin{tabular}{llll}
\hline & & Scorer1 & Scorer 2 \\
\hline Scorer 1 & Pearson Correlation & 1 & $\mathbf{. 8 6 9 ^ { * * }}$ \\
& Sig. (2-tailed) & & $\mathbf{. 0 0 0}$ \\
& N & 15 & 15 \\
Scorer 2 & Pearson Correlation & $.869^{* *}$ & 1 \\
& Sig. (2-tailed) & .000 & 15 \\
& N & 15 & \\
\hline
\end{tabular}

As Table 5. Shows, there was a high $(.86)$ and significant $(\mathrm{p}<.05)$ correlation between the two raters in the way they evaluated the written essays in terms of appropriate use of collocations. 
To find the effect of different ways of collocation instructions on students' writing skills, an independent sample t-test was run to compare the mean score of the two groups of the study.

Table 6. Group statistics

\begin{tabular}{llllll}
\hline & Group & $\mathrm{N}$ & Mean & Std. Deviation & Std. Error Mean \\
\hline $\begin{array}{l}\text { Writing } \\
\text { Scores }\end{array}$ & Experimental & 20 & 12.60 & 3.346 & .74 \\
& Control & 18 & 10.55 & 2.33 & .54 \\
\hline
\end{tabular}

Table 7. Independent samples test

Levene's Test

for Equality of t-test for Equality of Means

Variances

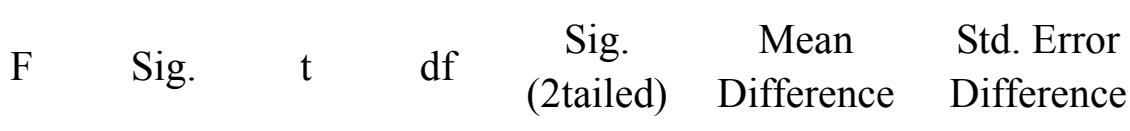

\section{Equal}

variances

assumed

$4.78 \quad .035 \quad 2.16 \quad 36$

Equal

Writing

Scores variances

not

assumed

\section{$\begin{array}{llll}2.20 & 33.97 & .035 & 2.04\end{array}$}

.946

$.037 \quad 2.04$

As Tables 6 and 7 suggest, there is a statistically significant difference between the writing scores of the experimental group $(M=12.60, S D=3.34)$ and the control group $[M=10.55$, $S D=2.33, t(36)=-2.16, p<0.05]$. The results of the data analysis reveal that students who experienced corpus-based instruction could significantly show a better use of collocations in their written essays compared to students who had been trained with conventional methods of collocation teaching. This result, however, does not imply that students in the control group did not show any progress in the use of collocations, as this is a comparative study making a comparison between two groups.

This finding partly affirms the findings of Jafarpour, Hashemian, and Alipour's study (2013) in proving positive effects of data-driven approaches on the comprehension and production of collocations and the study by Abu Alsharr and Abu Seileek (2013), which reported better writings for those L2 learners who were taught collocations via concordances.

The findings also support Yeh, Liou and Li's (2007) findings regarding students' use of more 
appropriate vocabulary, Anthony's (2006) findings in terms of students' better application of collocations in writing, and Yoon's (2008) findings as to their enhancement of knowledge of collocations and curtailing their writing problems after experiencing concordancing.

As for the third research question which aimed to explore students' perceptions and attitudes towards the use of concordancers and corpus, it was found that, in general, students had positive attitudes regarding the application of this approach. As to the advantages and disadvantages of using concordancers, in the semi-structured interviews, an interesting point was reported: that when working with the concordancer students could figure out the answers to many of the questions they would normally ask the teacher. They believed that corpus provided various examples indicating different uses and meanings of a word, which in turn enabled them to easily learn the items independent of the teacher. In this sense we can safely claim that the use of concordancers might contribute to students' autonomy, making them more responsible for their learning. Meanwhile, one cannot ignore the problems associated with this approach. In the course of the interviews, some students complained that the use of concordancer was boring and in some cases difficult, providing them with extra information they didn't really need. A few of the students mentioned the issue of accessibility of computers and concordancers and the fact that they faced limitations in this regard. Despite the potential problems mentioned for concordancers, there was a general agreement among students on the efficacy of their use in English language classes.

Findings of the interview is in line with the previous findings regarding overall positive attitudes of students towards using concordancers in the process of teaching (Chang \& Sun, 2009) as a writing tool (e. g. Yoon \& Hirvela, 2004) and their feeling of responsibility for their writing (Yoon, 2008). The interview results partly approve of the findings of Vannestal and Lindquist (2007) which reported reluctance on the part of some linguistically weak students' to the use of this reportedly "difficult" method.

\section{Conclusion and Implications}

As discussed above, using concordancers can improve students' verb-noun collocation knowledge. This result corroborates prior studies on the usefulness of concordancers and corpus in the process of language learning. As evident from the results of the data gathered at the beginning and end of study, students in the experimental group who experienced concordancer use in the teaching of collocations, outperformed the control group in collocation test. Moreover, it was found that students in the experimental group showed a better application of collocations in their writing, implying that the use of concordancers in teaching collocations leads to a better performance in writing tasks on the part of learners. Besides, the interview results reported that despite the few cases of potential negativity, overall, students had positive views and attitudes towards the application of concordancers in teaching collocations.

Findings of this study highlights the advantages associated with the use of concordancers, thus it can be particularly useful in material development, and course book writers can make use of corpus alongside with the softwares that are frequently designed nowadays in their teaching materials. English language educators, on the other hand, can implement concordancers, when applicable, as a part of collocation learning process in the classrooms and thereby enhance collocation acquisition and production of the students. The present study 
delved into the use of cocordancers for collocation learning and its use for students' writing production, further studies can be conducted to investigate the use of this technology on other language related areas such as speaking, vocabulary and grammar teaching. Subsequent studies can explore the effect of using concordancers for students in different levels to investigate which group of leaners can generally better profit the use of concordancers.

\section{References}

Abu Alsharr, A., \& Abu Seileek, A. F. (2013). Using concordancing and word processing to improve EFL written English. JALT CALL Journal, 9(1), 59-77.

Agah, M., \& Soori, A. (2015). Comparative Study of Collocation among the Languages. Language in India, 15(1), 527-537.

Anthony, L. (2006). Developing a freeware, multiplatform, corpus analysis toolkit for the technical writing classroom. IEEE Transactions on Professional Communication, 49(3), 25-32. http://dx.doi.org/10.1109/TPC.2006.880753

Ary, D., Jacobs, L. C., Sorensen, C., \& Razavieh, A. (2010). Introduction to research in education (8th ed.). Wadsworth: Cengage Learning, Belmont, USA.

Bagherzadeh Hosseini, M. S., \& Akbarian, I. (2007). Language Proficiency and Collocational Competence. The Journal of Asia TEFL, 4(4), 35-58.

Ebrahimi-Bazzaz, F., Samad, A. A. (2011).The Use of Verb-noun Collocations in Writing Stories among Iranian EFL Learners. English Language Teaching, 4(3), 158-163.

Ebrahimi-Bazzaz, F., Samad, A. A., bin Ismail, I. A., \& Noordin, N. (2015). Verb-Noun Collocations in Spoken Discourse of Iranian EFL Learners. International Journal on Studies in English Language and Literature, 3(3), 41-50.

Benson, M., Benson, E., \& Ilson, R. (1997). The BBI combinatory dictionary of English: a guide to word combinations: John Benjamins Publishing Co. http://dx.doi.org/10.1075/z.bbi1(2nd)

Chan, T. P., \& Liou, H. C. (2005). Effects of web-based concordancing instruction on EFL students' learning of verb-noun collocations. Computer Assisted Language Learning, 18(3), 231-251. http://dx.doi.org/10.1080/09588220500185769

Chang, W. \& Sun, Y. (2009).Scaffolding and web concordancers as support for language learning. Computer Assisted Language Learning, 22(4), 283-30. http://dx.doi.org/10.1080/09588220903184518

Chao, P. (2010). A study of collocation learning of junior high students in Taiwan via concordance. Paper presented at the 2010 international conference on English teaching, Kaohsiung, Taiwan.

Duan, M., \& Qian, X. (2012). Collocation in English Teaching and Learning. Theory \& Practice in Language Studies, 2(9), 1890-1894. http://dx.doi.org/10.4304/tpls.2.9.1890-1894

Goudarzi, Z., \& Moini, M., R. (2012). The Effect of Input Enhancement of Collocations in Reading on Collocation Learning and Retention of EFL Learners. International Education Studies, 5(3), 247-258. http://dx.doi.org/10.5539/ies.v5n3p247

Howarth, P. (1998). Phraseology and second language proficiency. .Applied Linguistics, 19(1), 24. http://dx.doi.org/10.1093/applin/19.1.24 


\section{Macrothink}

Journal of Social Science Studies

ISSN 2329-9150

2016, Vol. 3, No. 2

Hsu, J. T., \& Chiu, C. (2008). Lexical Collocations and their Relation to Speaking Proficiency of College EFL Learners in Taiwan. Asian EFL Journal, 10(1), 181-204.

Kennedy, G. (2008). Phraseology and language pedagogy. In F. Meunier, \& S. Granger (Eds.), Phraseology in Foreign Language Learning and Teaching (pp. 21-41). Amsterdam: John Benjamins. http://dx.doi.org/10.1075/z.138.05ken

Koosha, M., \& Jafarpour, A. A. (2006). Data-driven learning and teaching collocation of prepositions: the case of Iranian EFL adult learners. The Asian EFL Journal, 8(4), 192-209.

Lewis, M. (2000). Teaching collocation: Further development in lexical approach. London: Language Teaching Publications.

Lin, Y. P. (2002). The effects of collocation instruction on English vocabulary developments of senior high students in Taiwan. Unpublished Master's thesis, National Kaohsiung Normal University, Taiwan.

Liu, C. P. (1999). An analysis of collocational errors in EFL writings. In The proceedings of the Eighth International Symposium on English Teaching (pp. 483-494). Taipei, Taiwan: The Crane Publishing Co.

Liu, L. E. (2002). A corpus-based lexical semantic investigation of verb-noun miscollocations in Taiwan learners' English. Unpublished Master's thesis, Tamkang University, Taipei.

Mounya, A. (2010). Teaching lexical collocations to raise proficiency in foreign language writing. Unpublished Master's thesis, Guelma University, Algeria.

Nation, P. (2000). Learning vocabulary in lexical sets: Dangers and guidelines. TESOL Journal, 9, 6-10.

Nation, P. (2001) Learning vocabulary in another language. London: Cambridge University Press. http://dx.doi.org/10.1017/CBO9781139524759

Nesselhauf, N (2003). The use of collocations by advanced learners of English and some implications for teaching. Applied Linguistics, 24, 223-242. http://dx.doi.org/10.1093/applin/24.2.223

Nesselhauf, N. (2005). Collocations in a learner corpus. London: John Benjamins Publishing Company. http://dx.doi.org/10.1075/scl.14

Schmitt, N. (2004). Formulaic sequences: Acquisition, processing, and use. Philadelphia: John Benjamins. http://dx.doi.org/10.1075/11lt.9

Schmitt, N. (2008). Review Article: Instructed Second Language Vocabulary Learning. Language Teaching Research, 12(3), 329-363. http://dx.doi.org/10.1177/1362168808089921

Schmitt, N., \& Underwood, G. (2004). Exploring the processing of formulaic sequences through a self-paced reading task. In N. Schmitt (Ed.), Formulaic Sequences (pp. 173-189). Amsterdam: John Benjamins. http://dx.doi.org/10.1075/11lt.9

Shehata, A. K. (2008). L1 Influence on the Reception and Production of Collocations by Advanced ESL/EFL Arabic Learners of English. Ohio University.

Shokouhi, H., \& Mirsalari, G. H. (2010). Collocational Knowledge versus General Linguistic Knowledge among Iranian EFL Learners. Teaching English as a Second or foreign language, 13(4), 1-24.

Sinclair, J. (2003). Corpora for lexicography. In P. V. Sterkenberg (Ed.), A practical guide to 
lexicography. Amsterdam: John Benjamins. http://dx.doi.org/10.1075/tlrp.6.21 sin

Sinclair, J., M., Jones, S., \& Daley, R. (2004). English Collocation Studies: The OSTI Report, London: Continuum.

Sung, J. (2003).English lexical collocations and their relation to spoken fluency of adult non-native speakers. Unpublished Doctoral dissertation, Indiana University of Pennsylvania, Pennsylvania.

Tseng. F. P (2002). A study of the effects of collocation instruction on the collocational competence of senior high school students in Taiwan. Unpublished Master's thesis, National Taiwan Normal University, Taipei.

Vannestal, M. E., \& Lindquist, H. (2007). Learning English grammar with a corpus: Experimenting with concordancing in a university grammar course. ReCALL, 19(03), 329-350. http://dx.doi.org/10.1017/S0958344007000638

Wang, L. Y. (2002). Effects of inductive and deductive approach on EFL learning collocations patterns by using concordances. Unpublished Master's thesis, National Yunlin University of Science and Technology, China, Institute of Applied Foreign Languages.

Webb, S., Newton, J., \& Chang, A. (2013). Incidental learning of collocation. Language Learning, 63(1), 91-120. http://dx.doi.org/10.1111/j.1467-9922.2012.00729.x

Wilkins, D. A. (1972). Linguistics in language teaching. London: Edward Arnold.

Wray, A. (2002). Formulaic language and the lexicon. Cambridge: Cambridge University. http://dx.doi.org/10.1017/CBO9780511519772

Wu, S., Franken, M., \& Witten H. I (2010). Supporting collocation learning with a digital library. Computer Assisted Language Learning, 23(1), 87-110. http://dx.doi.org/10.1080/09588220903532971

Yeh, Y., Liou, H. C., \& Li, Y. H. (2007). Online synonym materials and concordancing for EFL college writing. Computer Assisted Language Learning, 20(2), 131-152. http://dx.doi.org/10.1080/09588220701331451

Youmei, G., \& Yun, Z. (2005). A Tentative corpus-based study of collocations acquisition by Chinese English language learners. Canadian Social Science, 1(3), 105-112.

Yoon, H. (2008). More than a linguistic reference: The influence of corpus technology on L2 academic writing. Language Learning \& Technology, 12(2), 31-48.

Yoon, H., \& Hirvela, A. (2004). ESL student attitudes toward corpus use in L2 writing. Journal of second language writing, 13(4), 257-283. http://dx.doi.org/10.1016/j.jslw.2004.06.002

\section{Copyright Disclaimer}

Copyright for this article is retained by the author(s), with first publication rights granted to the journal.

This is an open-access article distributed under the terms and conditions of the Creative Commons Attribution license (http://creativecommons.org/licenses/by/3.0/). 